\section{4. 金雨バリウムの䇺造}

從來会成 Ba の製造沉括いては，還元生成した $\mathrm{Ba}$ 蒸

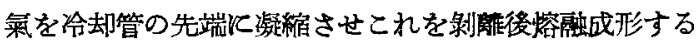
方法を用いている. 然し金屬 Baは活性が强いので, 冷

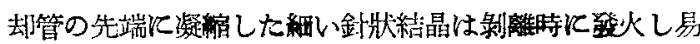

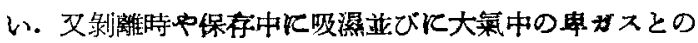

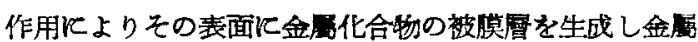
の純度が低下する．そこで蒸溜時により安定な譺樎层を

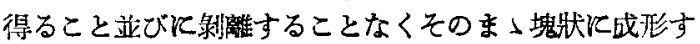
る方法によつて金庽 Ba を製造して見た。その結果,この

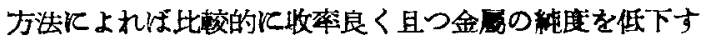
ることなく容易にインゴットを繁造し得る事が分つた。

裝置 ${ }^{(6)}$ は第 4 圖行示す如くである. 圖中 (c) の践坻堝
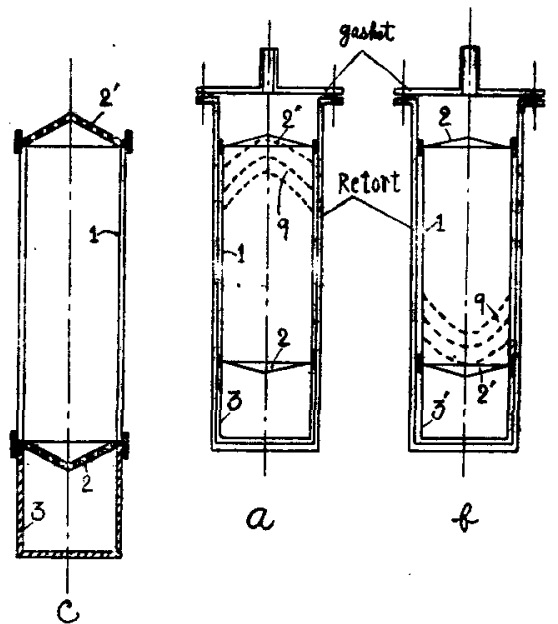

Fig. 4 Apparatus on the production of $\mathrm{Ba}$ metal

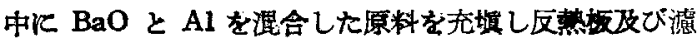

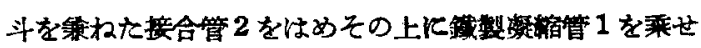

更反同样の接合管2をはめる。これらを(a) 固の如くレ

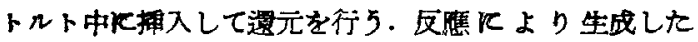

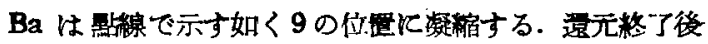

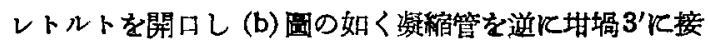
合してレトルト中搏入し Ar ガス歷下で加熱し Baを

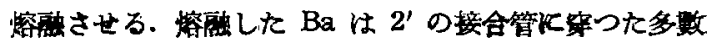

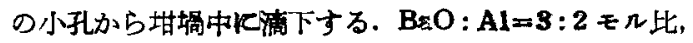
反應温度 $1,150^{\circ} \mathrm{C}$, 反鷹時間 $215 \mathrm{~min}$, 減暨度 $10^{-3} \mathrm{~mm}$ $\mathrm{Hg}$ 程度の條件汇て還元製造を行い，原料 $\mathrm{BaO}$ 亿對す るインゴット製造垬の百分率で 48～49\% の收率を得た。

\section{5. 總 括}

石英スブリング型熱天称を使用して，隇壓下の $\mathrm{BaO}$ のAl Kよる還元反鷹について撿討した.この摆元反應 は $1.040^{\circ} \mathrm{C}$ 位加ら始まり，原料の路合割合を蓄えた場 合, $\mathrm{Al}$ 少多量な程反應初期飞未ける $\mathrm{Ba}$ の生成速度は 大きいが Ba の收率は㱠んど變らない. 1,150 $\mathrm{C}$ の還元 で反應終了迄 $4 \mathrm{~h}$ を要し Ba の收率は $50 \%$ 前後であ る. 然し曼滋した BaO を用いた場合には上り低溫度か ら反應が開始するが Ba の收率低下寸る. しかしこれ らの閒の相閶々係については不明である. 向反焦により 生成するすのは $\mathrm{Al}_{2} \mathrm{O}_{3}$ ではなくバリウムフルミネート であり一憵反僬忙次式の如く進行するるのと推論した.

$$
6 \mathrm{BaO}+2 \mathrm{Al}=3 \mathrm{Ba}+3 \mathrm{BaO} \cdot \mathrm{Al}_{2} \mathrm{O}_{3}
$$

又金属 Ba の算造柿てついて記述した.

本呼究は興雷工業㧣式會㣂と其司で貫施したるのの一

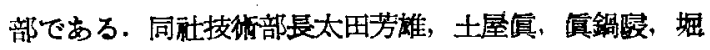
江賢司の諸氏の御協力を得た。

交 献

1. H. Goldschmit : 'Z. Electrochem. 4, 494(1898)

2. W. Biltz: Z. anorg, and allgem. Chem., 114, 245(1920)

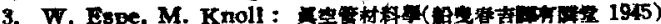

4. N.F. Mott : Trans. Farady Soc, 30, 472(1940)

5. 前川I: 工化, 45, $130(1942)$

6. 特样出四中

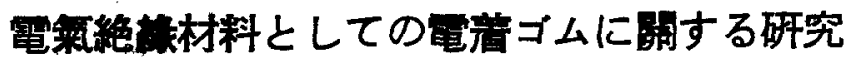

(第1報) ラテックス・ゴムの奄葿に影帮を及ぼす諸因子

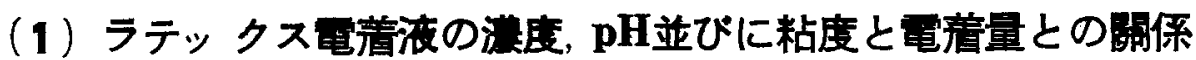

飯 沼 義 雄

(横清國立大學工悬部電氣化學科)

Studies on Electrophoretic Rabber Deposits for Rlectrical Insulation (Part 1) Factors Influencing the Flectrophoretic Depasition of Rubber

(1) Dependence of the Quantity of Electrophoretic Rubber Deposits on the Concentration, $\mathrm{pH}$ and Viscosity of Latex Baths

YOSHIO IINUMA

(Electrochemical Laboratory, Faculty of Engineering, National University of Yokohama, Yokohama) 
Certain variables, which have not yet been completely explained for electrophoretic deposition of rubber from latex baths in a wide range of concentrations have been investigated. The following experimental results, which may indicate some suitable conditions for a uniform electrophoretic deposit of high dielectric strength, have been obtained:

(1) It is important to regard the variables involved in the anophoretic deposition of latex rubber as interrelated.

(2) A suitable formula for a good deposition bath is as follows:

Latex (D.R.C., 60\%)

Formaline (38\%)

Sodium thiosulphate solution $(20 \%)$
Total solid
$\mathrm{pH}$
$37 \sim 47 \%$
$8.5 \sim 10.0$

(3) The suitable conditions for good deposition are as follows :

Working voltage

$D_{A}$

Temperature

$$
\begin{aligned}
& 10 \sim 30 \mathrm{~V} \\
& 1 \sim 3 \mathrm{~A} / \mathrm{dm}^{2} \\
& 18 \sim 25^{\circ} \mathrm{C}
\end{aligned}
$$

Duration of deposition $30 \sim 150 \mathrm{sec}$

(4) Except when the concentration of rubber in the latex bath is too high, the weight of rubber deposited per unit of current, namely, the current yield increases with the rubber concentration, passing through a maximum at a critical $\mathrm{pH}$ value of $9.0 \sim 9.5$, beyond which the current yield decreases with the concentration.

\section{(Part 2) Factors Influencing the EIectrophoretic Deposition of Rubber (2) The Electrophoretic Migration Velocity of Rubber Particles in Latex Baths}

After pointing out the fact that the dielectric strength of an electrical insulating material is governed by the uniformity of its structure and that the velocity of electrophoretic migration is a measure of the uniformity, it is shown that the anophoretic deposition at a constant or nearly constant apparent migration velocity renders securing the uniformity of deposits possible.

Calculations have been made to determine the apparent electrophoretic velocity of rubber particles in the latex bath, and the conditions required for a uniform deposition have been investigated. It has been found that the $\mathrm{pH}$ values satisfying these conditions are 9.5 $10.0,8.5 \sim 9.0$ and $8.5 \sim 10.0$ in the latex baths containing $30 \%, 40 \%$ and $50 \%$ of total solids respectively.

(Received April 14, 1952)

\section{1. 緒志}

一般に優秀な再氣絶緣性を具備した電氣絶線材料は如 何にしてこれを造るべきかの問題に對しては，明確な構 造論的知見を指標として呼究の步を進むべきととは論を 俟たないが，電釆絶楾材料として用いられる以上まず 一般材料として具備すべき必要條件の充足こて先決を姴 する課題と云わなければならない。

かような見地から，電氣絕線材料としての盖ゴムに 開する本研究においては，アンモニア保存ゴム・ラテッ クスから電氣泳動法により電着ざムを製造する䍖に必要

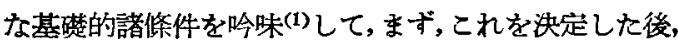

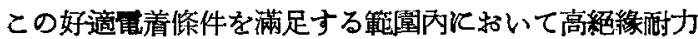
を登現させる零には如何なる條件が必要であるかを明ら かにする諸害驗を行い，一つの基本的原理を導き出すに 至つたので，その結果の概要をここに緾めて報告する．

周知のよ5に，ラテックス電着液より陽極へのゴム電 着量並びに電着ゴムの性質（殊に含水量の多寡）使用 電着液のゴム澧度，添加電解質及びゴム配合劑の種類と

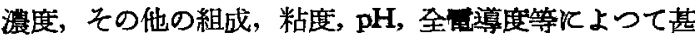
しく相量するばかりでなく，同一電着液においても，雷
着裝置, 殊飞隔膜の有無, 電極の種顂及び配置, 使用電㻺,

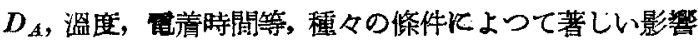
を受ける。

本啹においては，高紹緣酎力を具備した電着ゴムを得 る焉に必要な榙條件を明らかにする研究の基礎として, ラテックス・ゴムの麗着實施上問題となりながら，ゴム

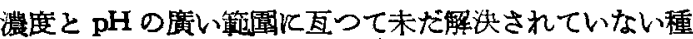
々の感着條件を吟味する篇，まず，ゴム配合㑊を含まぬ アンモニア保存ラテックスより陽極へのゴム電着行影㲎 を及恬す諸因子を璉々䌈更して貫驗を行つた結果の概要 を報告する。

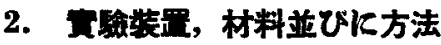

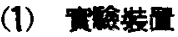

ラテックス・ゴムの陽極盘目法には，陽極上にゴムを 直接国着させる方法及び陽極をラテックス液には直接接 䚡せしめず，陽極の㓮圍に設けた隔膜上にゴムを沈着さ せるす法とがあり，更汇第一のう洷注は，隔膜を使用せ 风場合とこれを使用する場合，郎ち隔膜內にラテックス 能着液と陽極を入れ，その外側に稀アンモ二ア水と陰極 を入れて蛅着を行う場合とがある.隔膜を使用する方法 
によれば，ラテックス・ゴムの電着反應に伴ない生起す る水の電解により㓌極に發生する水素ガスの影整を受け ることなく陽極へのゴム苩着を具合よく行い得ると同時 飞，電氣唀の作用により電着物の脫水作用並びに隔膜 を通して $\mathrm{H}^{+}, \mathrm{NH}_{4}+, \mathrm{K}^{+}$等の陽イオンと共に榇液中の 水分が陰極室に移動し，しかす，この場合，隔膜を通し て流れる水量はゴム粒子の電着により丁度過剩となる水 量にほほ等しく，且つ $\mathrm{NH}_{4}{ }^{+}$等の除去も負荷再ゴム粒子

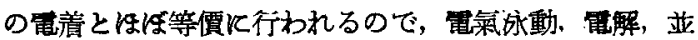
びに篗氣透 3 者の合同作用の結果として短時間の場合 そは，電着液の組成や濃度等にたいした縤動を見ること なく䉓着操作を繼續し得るなど種々の利點がある。

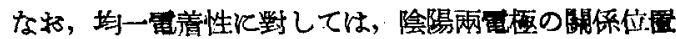
が重要な役割を演ずるので，これらの諸點を吟味するこ とにより，本害驗に括いては，總て第1圆に記載の寸法 及び配置の隔膜を䚚えた電着害驗狀固を使用した。

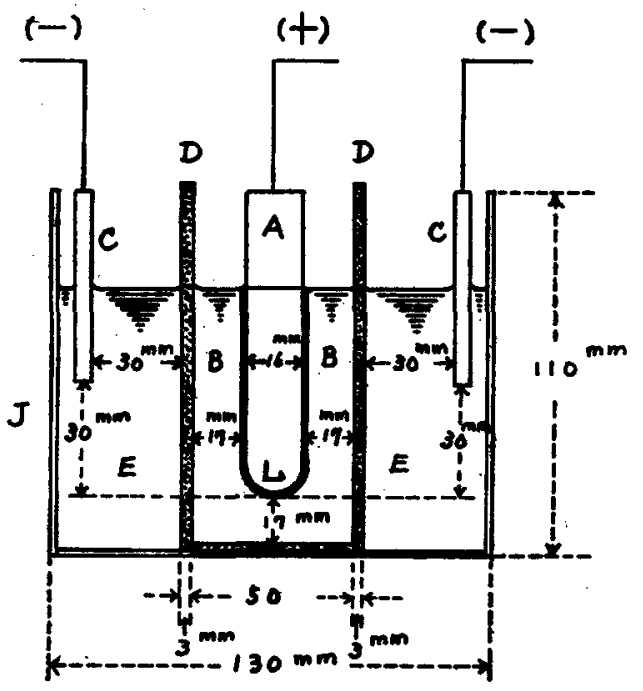

第 1 娄

A …踼杼（純亞鉛製）

B・..隄柱液（ラテックス電着液）

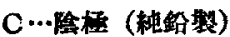

D...隔膜（微多孔質素煳製）

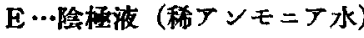

J …九型ガラス棈

L…電青ゴム

(2) 材 料

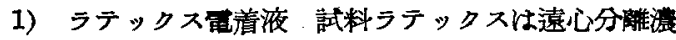
樎法によるアンモニア保存ラテックスを使つた. その組 成及び性狀の概䊀は全固形分 $61.51 \%$ ，純ゴム分60.0\%， アンモ $=$ ア 0.59\%, 比重 0.951 , pH 9.8 である.

この試料 100 部 (重量比, 以下同樣) そアンモ二ア除 去乵として 38\%フォルマリン4部を加えてよく混合し

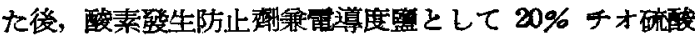
ソーダ溶液 5 部を添玑して $\mathrm{pH}$ を 8.15 , 全篗導度を 7 $\sim 8 \times 10^{-3} \Omega^{-1} \mathrm{~cm}^{-1}$ 以上, 全固形分を $56 \%$ としたるの (L-0) を陽極液とし，陰極液には 0.3〜0.5\%の稀アン モニア水を使用した.

2）陽極 陽極の材料としては酸化され易く且つ溶解 性で, しかる，その生成物がゴム江有害な作用を及ぼさね あのを使用することが必要である. 陽極が不溶解性の材 料であれげ容易に水笪解が起り酸素を發生し易いから， 可溶性の材料でなければならないととは云うまでるな い.な拓，可溶性の金屬から發生する陽イオンはそのま ま電着物中にはいるから，鋼のようにゴムの老化を促進 するよ5な有害なるのであつてはならない。從つて，か よ5な目的對しては， $\mathrm{Zn}, \mathrm{Mg}, \mathrm{Cd}, \mathrm{Pb}, \mathrm{Sn}$ 等を使用 できるが，これらの5ち，亞鈶は弱アルカリ性溶液で使 用するのに都合が好く，且つ，その酸化物である亞路華 は笔着ゴム中に混入し，加硫促進齊の機能を强化する加 硫促進活性就として强力に作用する活かりでなく，而着 ゴムの機械的性能を玫善する補强劑として作用する利點 ああるので，陽極材料としては亞鉊が最も䔔當である。

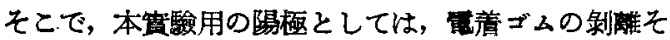
の他の取扱の容易，線端交果の防止及び宣用價值制定の

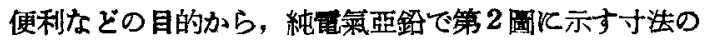
指サック型圆筒狀電極を作り，且つ，その藏着面積を正 確に $30 \mathrm{~cm}^{2}$ に規定するため，電極の上方側面に筑氣絶

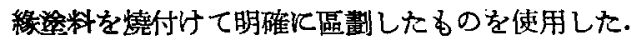

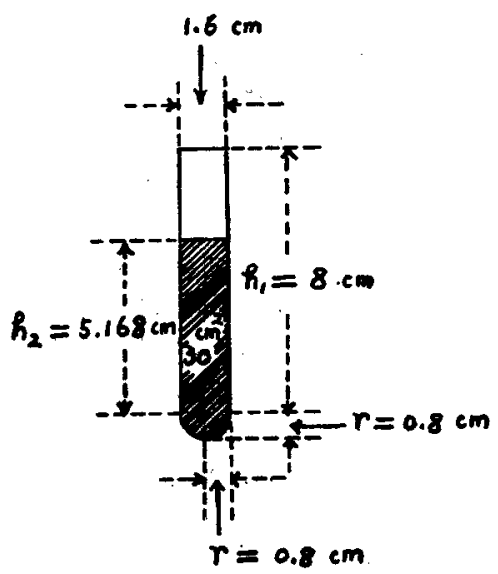

第 2 圆

3) 陰極 陰極には厚さ $2 \mathrm{~mm}$ ，大きさ $5 \mathrm{~cm} \times 8 \mathrm{~cm}$ の純銛板を牛圓弧狀にして，とれを1晕使用した。

4) 隔膜 隔膜としては厚さ $3 \mathrm{~mm}$, 內象 $4 \mathrm{~cm}$, 高さ $15 \mathrm{~cm}$ の钼多孔質素燒製の圓筒を使用した.

\section{（3）倠方方法}

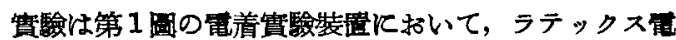
菁液のゴム濃度, その他の組成, $\mathrm{pH}$, 溫度, $D_{A}$, 使用的

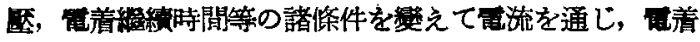

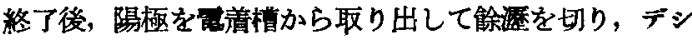




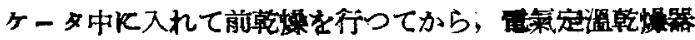
К括いて 70

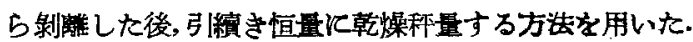

な括，ラテックス液の $\mathrm{pH}$ を低憾させるため，交献と

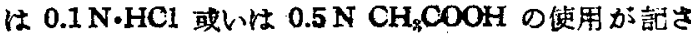
れているが，ラテックス液はこれら試菜の棌加により， 局部的の凝固を起すのて，pH 請管用として迤當とは考

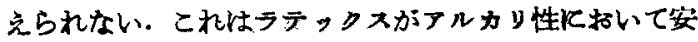
定な炼水性のニロイドであることからすれば寧る黨然の ととと云わなけ机な゙ならない。

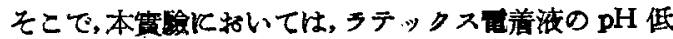

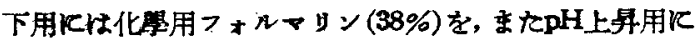

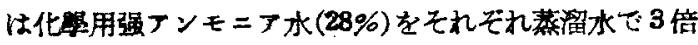

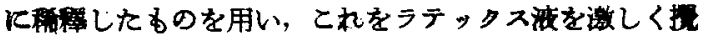
汼しながら徐々に，そして果進的飞添加し， $\mathrm{pH}$

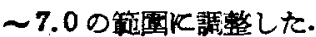

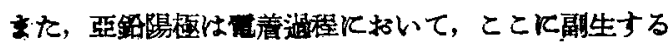
酸素甘スのため酸化作用を受けて亞銛華を生成するばか

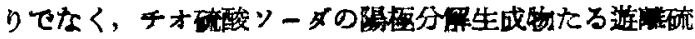

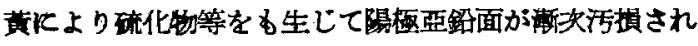

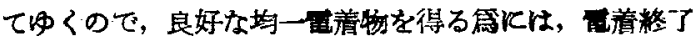

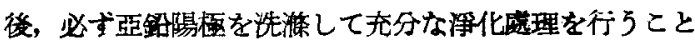

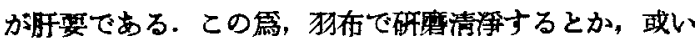

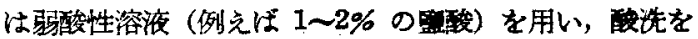
施すなど色々の方法はあるが，手數が煩と雜であるか，

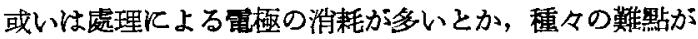
あり，いずれる適當とは認められない。

然るに，電着を行了前に穆じめ，

$\mathrm{NaCN}$ または $\mathrm{KCN} \cdots . . .75 \mathrm{~g}, \mathrm{ZnO} \cdots . . . .45 \mathrm{~g}$,

$\mathrm{NaOH} \cdots \cdots . .15 \mathrm{~g}, \mathrm{H}_{2} \mathrm{O} \cdots \cdots . .1 l$,

ゼラチンまたはフラビヤゴん……若干

のよ5な組成のアルカり性亞的 ( 扔いて, 溫度 $50^{\circ} \mathrm{C}$, 電流密度 1 2 A/dm² て $30 \sim 120 \mathrm{sec}$,

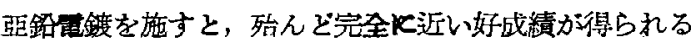

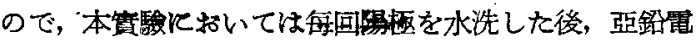
鍍を施す万法を採用した。

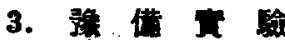

ゴム配合劑を含ま奺テンニア保存ラテックスより電

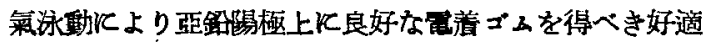
電着條件を铸へる篇，全固形分として 15〜56\% の廣い

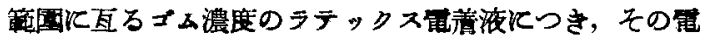

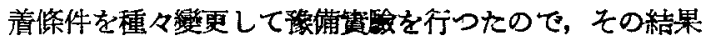
の一部艺文に摘錄する。

(1) ゴ内洪度の著し〈高いフンモニア保在ラテックス

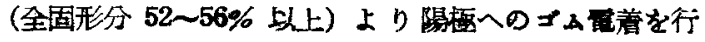

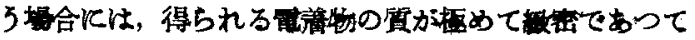

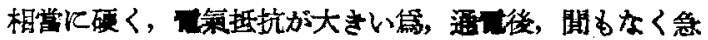

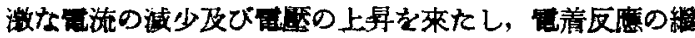

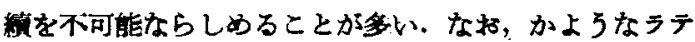

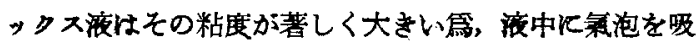

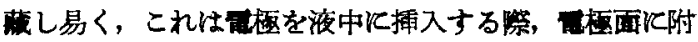

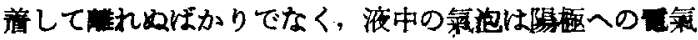
泳動を起し，西着ゴム詹に氣泡を生じ易い原因となる。

（2）ゴム灌度の著しく低いアンモニア保存ラテックス （全固形分 15\% 以下）よりゴム電着を行了時は，多是

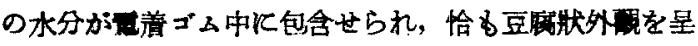
し，しかす非常炕軟かくブョブョしているので，取报い が甚だ园蜼であるばかりでなく，とれを畭煤すると，多

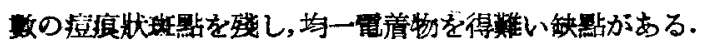

（3）ラテックス雷着液としては，重量比で

$$
\begin{aligned}
& \text { ラテックス（ゴム分 60\%)……...100 部 } \\
& \text { フォルマッン (38\%)……........3 5 部 } \\
& \text { チオ硫酸りーダ (20\%)….......5 7 部 }
\end{aligned}
$$

より成る配合液を蒸溜水て稀釋して，一般的注全固形 分を37〜 47\%程度， $\mathrm{pH}$ を 8.5 10.0 程度飞調整したも のが適當である.

（4）ラテックス・ゴムの電着槽と括いて隔膜を使用し ない場合には，隔膜の抵抗がない篇，それだけ使用電壓

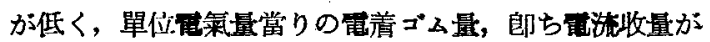

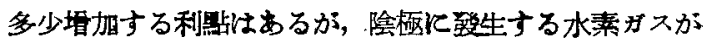

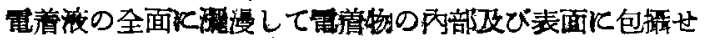
られ，その品賀を害する缺點があるので，良好な均一電

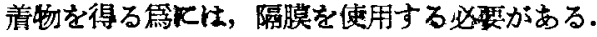

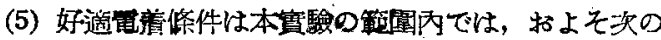
通りである.
使用㫣啀 $.10 \sim 30 \mathrm{~V}$

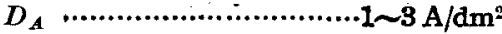

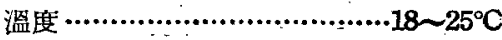
電着繼續時間…................30～150 sec

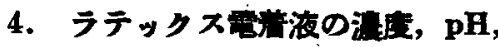

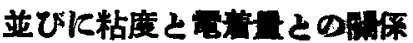

一定電氣量炕より得られる震着る゙ム量がラテックス電

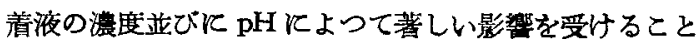
は古くから知られているが，從來報告せられている結果 は必ずしす同樣ではないので, ここでは, 重量比で, ラ テックス (ゴム分60\%) 100 部，フャルマリン(38\%) 3

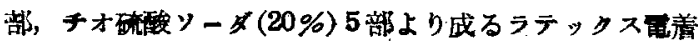

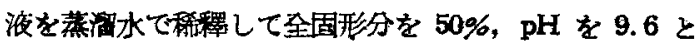
したもの (L-1) から出發して，その全固形分を $50 \%$ から脂次 40\% (L-2)，90\% (L-3)，20\% (L-1) K戀元る

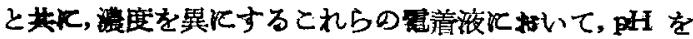
10.5 か.ら 7.5 まて 0.5 ずつ低めていつた㵵合につき，

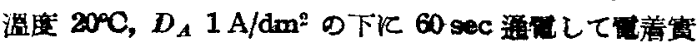




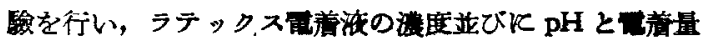

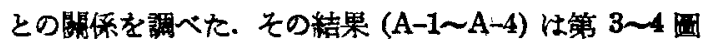

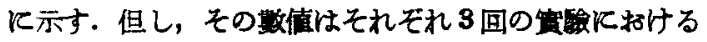
本均值である.

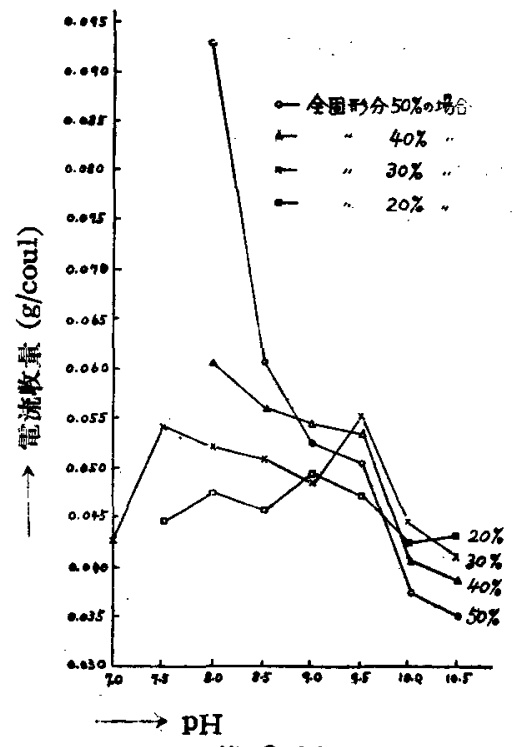

第 3 嘈

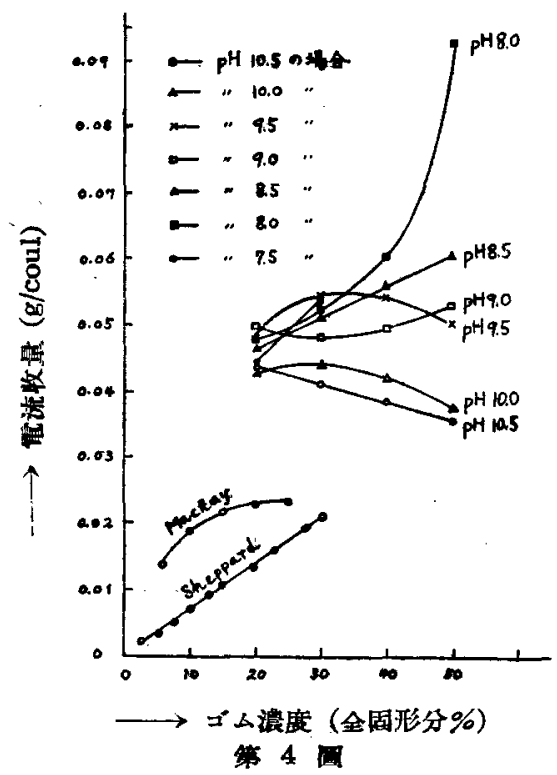

また，第5圖は全固形分がそれぞれ 50\%，40\%，30\% 及び 20\% なる上記ラテックス電着液 ( $(L-1 〜 L-4)$ の $\mathrm{pH}$ を 10.0 から 7.5 まで 0.5 ずつ低めていつた坫合 飞つき，溫度 $25^{\circ} \mathrm{C}$ 飞打いてオストワルド粘度訢を用いて 粘度測定を行い，ラテックス喜着液のゴム濃度及び $\mathrm{pH}$ と比粘庭との關係を調へた結果（A-5）を示したのので ある.

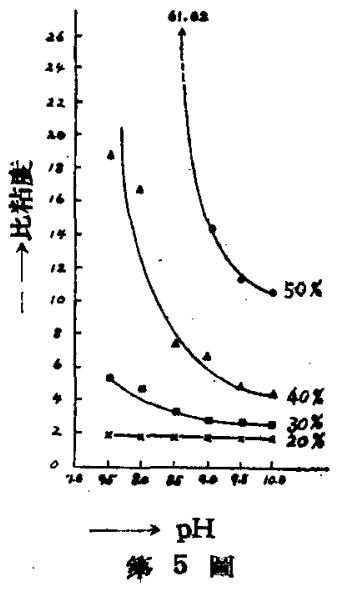

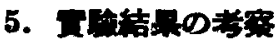

アルカリ性ラテックス液 て抛て pH を高くするこ と, 或いはアルカリを添加 するととば，ラテックス管 着液の全祖導庭を壖加させ ることにはなるが,これは

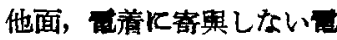
流成分，即亏五军質鼠流を 大きくすること役立つわ

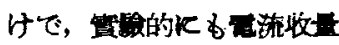
はラテックス電着液の全震

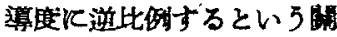

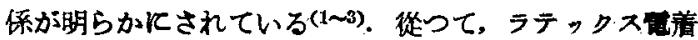

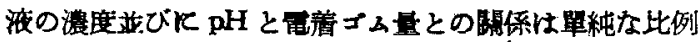
開係を涩足するるのではなく，ある一定の湜度及び $\mathrm{pH}$ 值に括いて的着ゴム量が熶大值を示すだろうとい5こと が推定される.

ところで, ラテックス・ゴム粒于の陽極への严着速度

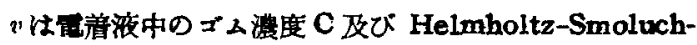
owski の式

$$
\mu=\frac{\zeta \varepsilon E}{4 \pi \eta}
$$

そよつて與克られる粒子の平均泳動速度 $\mu(\mathrm{cm} / \mathrm{sec})$ K 比例する。，但し，反は浮遊している固體粒子及び湤體の

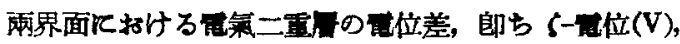

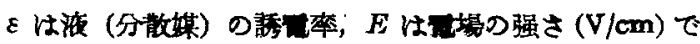
ある.

そとで,上式を絞換して，

$$
\frac{\mu}{E}=\frac{\zeta \varepsilon}{4 \pi_{\eta}}=\mu_{0}
$$

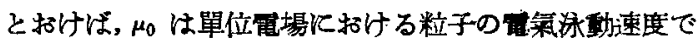
あつて, 單位は cm/sec/V/cm である.

從つて，目着速度、はゴム粒子の有与る骮荷比比例し て速くなり，しかわ，乙の苚荷は『ルカりの添加によつ て次第化剒大与る開係があるから，ゴム浱度が大きくな る程，また $\mathrm{pH}$ が高くなる程，電流收量は增大するだる 万といらととが一應䝮期される。郎ち、ゴム濃度 $15 \%$ の ラテックス液につき, $\mathrm{pH}$ 值 6.0 9.1 亿扔いては電流收 量と pH との開比比例開係が成立するが，pH 值 9.1 9.9 亿和いては成立せず,多くの場合, $\mathrm{pH}$ 值 9.1 亿打い

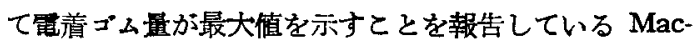
kay の研究 ${ }^{(3)}$ は上上の推定を菑證する一例であつて, 全 固形分 20\% のラテックス電着液について管者の行つた

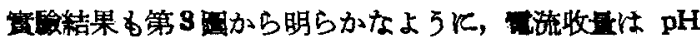
9.0 К颃いて，最高值を示してょり，大體これと一致し ている. 
しかし、ゴム潩度が高くなると最大電着量を示す $\mathrm{pH}$ 值は高いす移動し，全固形分 $30 \%$ のラテックス電着 液沉括いては 9.5 附近の $\mathrm{pH}$ 值にての最大值が認めら れる.更とゴム䈨度が高くなり，例えば，全固形分が50\%

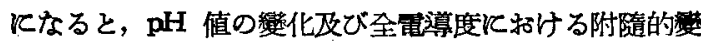
化に基因する影響の法汃，粘度變化による影響が大き く作用して來るので，その趣著しく違つて來る．郎ち 第 5 圆から明らかなよ 5 Kフォルマリンの添加により $\mathrm{pH}$ を低下させる場合，全固形分 20〜30\% と招いては粘 度の上皉はたいして見られないが，40\%では可なり影著 となり，全固形分 50\%のようとゴム濃度か著しく高い

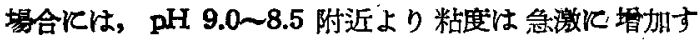

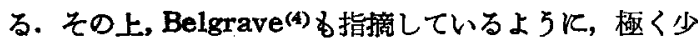

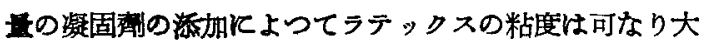
きく綎化するので，この問題は益々錯雜なるのとなる。

な括; 考の雼飞 Sheppard(2) 及び Mackay(3) の盲 值を第4 国示したが，とれを筆者の惯验做と比較し て見ると, 兩氏の結果は筆者の確認した結果のある特定 の範園に打いてのみ定性的に一致する.

これを要すると，ゴム濃度と電着量との關係を正確に 規定するには, pH 值を導入する必要があるのであつ て, 第4 圖から明らかなよ 万反, pH 9.0〜9.5 を境とし て，とれより小さい $\mathrm{pH}$ 值においては電着ゴムの筆流收 量はラテックス電着液のゴム漊度には正比例し，この 境界值より大なる $\mathrm{pH}$ 值沉招いては雨開係の傾斜は中や 䌅かではあるが，はば反比例することが制る。

いずれにせよ，優秀な妁一電着ゴムを得る馬には，ラ テックス・ゴムの隄極電着に影響を及にす諸因子の相互 闒逨性を重視して操作すべきであり，ガスの發生もしく はとの影響を防止すると共に, ラテックス電着液のアル カリ度, 從つて $\mathrm{pH}$ 值をその組成, 全固形分, 全電尊度 等と睨み合せて，ある狹い好適條件の範圖內に保持する ことが極めて肝要である。

\section{6. 總括}

高絶緣酎力を具備した電着ジムを得る爲に必要な諸條

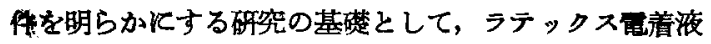
より陽極へのゴム電着に影響を及ぼす諸因子を種々變更
して置詅を行い，夹の事項を確めた。

(1) ラテックス・ゴムの陽極雷着に影䚀を及ほすす諸因 子火ついては，それらの相互閵連性を重視して操作する ことが必要である。

(2) ラテックス電着液としては, 重量比で, ラテック ス (ゴム分60\%) 100 部, フォルマリン(38\%) 3〜5 部, チオ硫酸ソーダ (20\%) 5〜7 部より成る配合液を蒸溜水 て稀釋して,一般的に恃全固形分を $37 \sim 47 \%$ 程度, $\mathrm{pH}$ を8.5〜10.0 程度に調整したものが適當である.

(3) ラテックス・ゴムの電着槽に括いて隔膜を使用し ない場合には，隔膜の抵抗がない鳳，それだけ使用電壓 が低く，篦流收量が多少增加する利點はあるが，陰極に 發生する水素ガスが電着狀態惩影響る及洼すなどの缺 點があるので，良好な均一雷着物を得る爲には淂膜を使 用する必要がある.

（4）好適電着條件は本竀驗の範圍內では次の通りであ る.

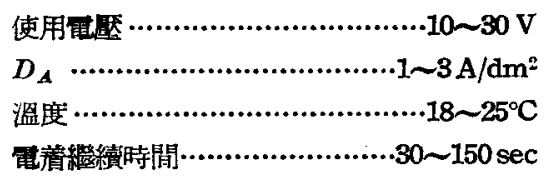

(5) ラテックス電着液の濃度亚びに $\mathrm{pH}$ と笛着ゴム量 との烈係は單純な比例關係を滿足するものではなく， ゴム清度の著しく高い場合を除けば，ある一定の $\mathrm{pH}$ 值 (9.0〜9.5) と括いて䉓着ゴム量は最大值を示す.として, この $\mathrm{pH}$ 值を境として，これより小さい $\mathrm{pH}$ 值において は電流收量はラテック ス電着液のゴム濃度にほぼ正比 例し，これより大きい $\mathrm{pH}$ 值に执いては兩關係の傾斜は やや援かではあるが，ほば反比例する。

終りに，本貫驗に協力された今牧省悟君に愿く感謝す ろ.

女献

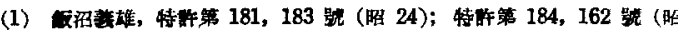

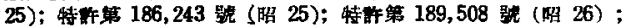

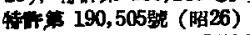

(2) Anon: Ind. Rub. Wld., Aug. 35 (1935)

(3) Sheppard: Trans. Am. Electrochem. soc., 52, 47 (1927)

(4) Mackay: Trans, Inst., Rub. Ind., 7, 254 (1931); Rub. Chem. \& Tech., 5, 232 (1932)

(5) Belgrave: Mal. Agric. J., 1 1, 348 (1923)

\section{（第 2 報）ラテッ クス・ゴムの菓瞄に影響を及ぼす諸因子 （2）ラテックス電着液におけるゴム粒子の電乘泳動速度}

\section{1. 粕震}

一般飞近代的な工業生産飞预いては，如何なる製品で す均一性が基調をなしているが，就中，雪氣紹緣用に供 する材料及び製品においては，特にとの均一性を確實に 保持できるか否かが致命的重要性を有するすのである. そこで，電着被膜の均一性とい5見地加らすると，これ
は霞氣泳動速度の常に一定もしくは一定に近いところで 得られる筈であるから，電着に伴な5ラテックス電着液 の䈨度及び $\mathrm{pH}$ の變化とゴム粒子の電氣泳動速度との開 係を知る必要がある。

・本報にまいては，高紹緣耐力を具備した霓着ゴムを得 る鳥に必要な諸條件を明らかにする研究の基碟として, まず, 前報(1)の實驗結果を基にして濃度及び $\mathrm{pH}$ を異に 